Article

\title{
Identification of Novel 1,3,5-Triphenylbenzene Derivative Compounds as Inhibitors of Hen Lysozyme Amyloid Fibril Formation
}

\author{
Hassan Ramshini ${ }^{1}$, Reza Tayebee ${ }^{2}$, Alessandra Bigi ${ }^{3}{ }^{\circledR}$, Francesco Bemporad ${ }^{3}$, \\ Cristina Cecchi ${ }^{3}(1)$ and Fabrizio Chiti ${ }^{3, *}$ \\ 1 Biology Department, Payam Noor University, Tehran 19395-4697, Iran; ramshini@alumni.ut.ac.ir \\ 2 Department of Chemistry, School of Sciences, Hakim Sabzevari University, Sabzevar 96179-76487, Iran; \\ rtayebee@hsu.ac.ir \\ 3 Section of Biochemical Sciences, Department of Biomedical, Experimental and Clinical Sciences, University \\ of Florence, I-50134 Florence, Italy; alessandra.bigi@unifi.it (A.B.); francesco.bemporad@unifi.it (F.B.); \\ cristina.cecchi@unifi.it (C.C.) \\ * Correspondence: fabrizio.chiti@unifi.it; Tel.: +39-055-275-1220
}

Received: 25 October 2019; Accepted: 2 November 2019; Published: 7 November 2019

\begin{abstract}
Deposition of soluble proteins as insoluble amyloid fibrils is associated with a number of pathological states. There is a growing interest in the identification of small molecules that can prevent proteins from undergoing amyloid fibril formation. In the present study, a series of small aromatic compounds with different substitutions of 1,3,5-triphenylbenzene have been synthesized and their possible effects on amyloid fibril formation by hen egg white lysozyme (HEWL), a model protein for amyloid formation, and of their resulting toxicity were examined. The inhibitory effect of the compounds against HEWL amyloid formation was analyzed using thioflavin $\mathrm{T}$ and Congo red binding assays, atomic force microscopy, Fourier-transform infrared spectroscopy, and cytotoxicity assays, such as the 3-(4,5-Dimethylthiazol)-2,5-Diphenyltetrazolium Bromide (MTT) reduction assay and caspase- 3 activity measurements. We found that all compounds in our screen were efficient inhibitors of HEWL fibril formation and their associated toxicity. We showed that electron-withdrawing substituents such as $-\mathrm{F}$ and $-\mathrm{NO}_{2}$ potentiated the inhibitory potential of 1,3,5-triphenylbenzene, whereas electron-donating groups such as $-\mathrm{OH},-\mathrm{OCH}_{3}$, and $-\mathrm{CH}_{3}$ lowered it. These results may ultimately find applications in the development of potential inhibitors against amyloid fibril formation and its biologically adverse effects.
\end{abstract}

Keywords: protein misfolding; HEWL amyloid aggregation; drug discovery; small aromatic compounds; amyloid inhibitors; triphenylbenzene

\section{Introduction}

The conversion of peptides or proteins from a soluble state into insoluble, $\beta$-sheet rich, fibrillar aggregates, generally called amyloid fibrils, is a key event in a large family of human pathologies, including neurodegenerative and non-neuropathic systemic amyloidosis [1,2]. Among these, Alzheimer's disease (AD) is the most known and diffuse and it has an increasing incidence in the worldwide population. Similarly, Parkinson's disease (PD), as well as Huntington's, prion diseases, type II diabetes, and systemic amyloidosis share the common hallmark of amyloid fibrillar aggregates [1-3]. Although the proteins that comprise these deposits do not share any sequence or structural homology, amyloid fibrils formed by different proteins share similar structural and physicochemical properties and, possibly, a common pathogenic mechanism [4,5]. These diseases involve self-assembly of soluble proteins into large insoluble fibrils through nucleation-dependent 
assembly, often via the formation of oligomeric structures that possess toxic properties $[1,6,7]$. Therefore, preventing oligomer and fibril formation appears an attractive approach to tackling the progress of such diseases.

Fibril formation is a polymerization process which can be simply described by a sigmoid curve with three phases, originally suggested to be a three-stage process consisting of nucleation, fibril elongation, and the final plateau [8], although the most recent progress has elucidated that each of the three phases involve a combination of the various microscopic steps $[9,10]$. Despite intensive efforts to treat amyloid-associated diseases, there is no fully effective and definitive treatment of such diseases $[1,2,11,12]$. Several strategies have been undertaken in the attempt to interfere with the formation and deposition of amyloid fibrils and their pathogenic role, including inhibition of the formation of the amyloidogenic form of proteins by stabilization of the native conformation, reduction in the production of the amyloidogenic sequence from a more complex protein, inhibition of protein self-assembly in oligomers and fibrils, and enhancement in the clearance of toxic aggregates [13-17].

The propensity of proteins and peptides to form amyloid fibrillar structures is correlated to their physicochemical properties such as net charge, secondary structure tendency, hydrophobicity, and aromatic interactions $[18,19]$. Regions of the sequence of proteins promoting amyloid fibril formation are often enriched with aromatic residues [20-22]. There are different hypotheses on the precise role of the aromatic residues in the amyloidogenic process. One of them suggests that aromatic amino acid residues promote peptide self-assembly for their hydrophobic nature, high $\beta$-sheet propensity and null charge, along with their planar geometry that are the most relevant factors in self-assembly [23-27]. According to this hypothesis, the aromatic nature of these residues does not contribute significantly to their amyloidogenicity. Other various studies suggest that aromatic amino acids contribute to peptide self-assembly through $\pi$-stacking interactions $[22,28,29]$. Other groups also believed that both hydrophobicity and aromaticity play a role in the self-assembly [30]. Regardless of the precise mechanism by which aromatic residues drive amyloid fibril formation, the parallel in-register alignment of $\beta$-strands in amyloid fibrils contributes to create a stacking of aromatic rings along the fibril axis. Thus, aromatic compounds may competitively interact with aromatic residues in amyloidogenic proteins, preventing their stacking, and block the self-assembly process [31]. It has been found that the effect of aromatic compounds on amyloid aggregation strongly depends on their structure and functional groups [32,33]. Multiple studies have reported that the number of phenyl rings and electron-withdrawing or -donating groups on the molecules, as well as their positions, are important characteristics that determine the effectiveness of the aromatic compounds in their inhibition of $A \beta$ aggregation [34-36]. Following this concept, six aromatic molecules belonging to the category of 1,3,5-triphenylbenzene and having different electron-donor or -withdrawing substituents, have been synthesized and their possible effects on amyloid fibril formation by a sample protein have been tested. As a sample protein we have chosen hen egg white lysozyme (HEWL), as it is known to form amyloid fibrils under appropriate conditions [37-40] and because the properties of the resulting fibrils and the of the overall amyloid formation process have been investigated to a significant extent $[41,42]$. The effects of the compounds on amyloid fibril formation by HEWL and on the biological properties of the resulting aggregates have been investigated through the use of various techniques, including Congo red (CR) and thioflavin T (ThT) assays, Fourier-transform infrared (FTIR) spectroscopy, atomic force microscopy (AFM), the MTT reduction assay, and caspase activity measurements. Our results showed the importance of the substituents on the efficiency of aromatic compounds, with compounds containing electron-withdrawing substituents having greater efficacy in HEWL amyloid inhibition, thus representing promising compounds for developing inhibitors of amyloid fibril formation. 


\section{Results}

\subsection{Chemistry of the Compounds}

Scheme 1 shows a general formula for the preparation of some para-substituted 1,3,5-triphenylbenzenes (compounds 1-6). These pharmaceutical important compounds are made by the condensation of aryl methyl ketones catalyzed by HPA/NCP under solvent-free conditions. Nanoclinoptilolite (NCP) refers to a natural zeolite composed of a microporous arrangement of silica and alumina and also HPA $\left(\mathrm{H}_{6} \mathrm{P}_{2} \mathrm{~W}_{18} \mathrm{O}_{62}\right)$ refers to the Wells-Dawson heteropolyacid. The heteropolyacid catalyst activates the carbonyl group toward the electrophilic substitution. Using this procedure, six compounds belonging to the category of para-substituted 1,3,5-triarylbenzenes have been synthesized and purified as previously described [43,44]. These are 1,3,5-triphenylbenzene (Compound 1); 1,3,5-tris(4-fluorophenyl)benzene (Compound 2); 1,3,5-tris(4-nitrophenyl)benzene (Compound 3); 1,3,5-tris(4-methylphenyl)benzene (Compound 4); 1,3,5-tris(4-methoxyphenyl)benzene (Compound 5); and 1,3,5-tris(4-hydroxyphenyl)benzene (Compound 6).

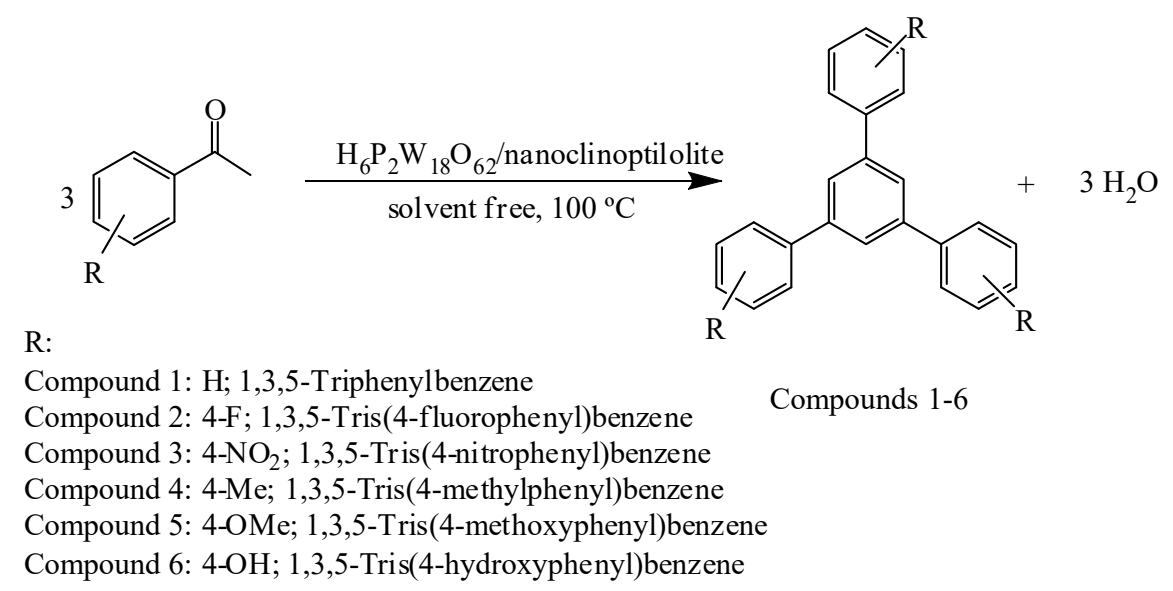

Scheme 1. General formulation for the cyclotrimerization of acetophenones.

The names and chemical formulas of the six compounds are reported in Scheme 1. Their NMR spectra are reported in the supplementary information, again along with their chemical formulas (Figures S1-S6).

\subsection{Effect of 1,3,5-Triarylbenzenes and Their Derivatives on Heat-Induced Fibrillation of HEWL Monitored with ThT Fluorescence}

The inhibition potential of the six compounds was determined using the ThT fluorescence assay to measure the amount of amyloid aggregates after the addition of various concentrations of each compound ranging from 0.03 to $2.6 \mu \mathrm{M}$. Aggregation of HEWL was induced by incubating the protein for $48 \mathrm{~h}$ at a concentration of $2 \mathrm{mg} / \mathrm{mL}(140 \mu \mathrm{M})$ in $50 \mathrm{mM}$ glycine buffer, $\mathrm{pH} 2.5$, and $57^{\circ} \mathrm{C}$, while stirred gently by magnetic bars (rpm 250), in the absence or presence of 0.03-2.6 $\mu \mathrm{M}$ compounds 1-6. All compounds clearly showed a pattern of dose-dependent inhibition, as suggested by the observed decrease of ThT fluorescence intensity (Figure 1). The $\mathrm{IC}_{50}$ values of the compounds, corresponding to the concentration at which the inhibitory effect is half of the maximum effect, were determined (Figure 2). The relative order of efficacy of the compounds in terms of $\mathrm{IC}_{50}$ value is compound $2>$ compound $\mathbf{1}>$ compound $\mathbf{3} \sim$ compound $\mathbf{5}>$ compound $\mathbf{4}>$ compound $\mathbf{6}$ and, thus, compound $\mathbf{2}$ is the best inhibitor and compound 6 has minimum effect in this process. As shown in Figures 1 and 2 , $0.32 \mu \mathrm{M}$ of all compounds significantly inhibited the aggregation of HEWL, thus this concentration was used for the subsequent experiments. 

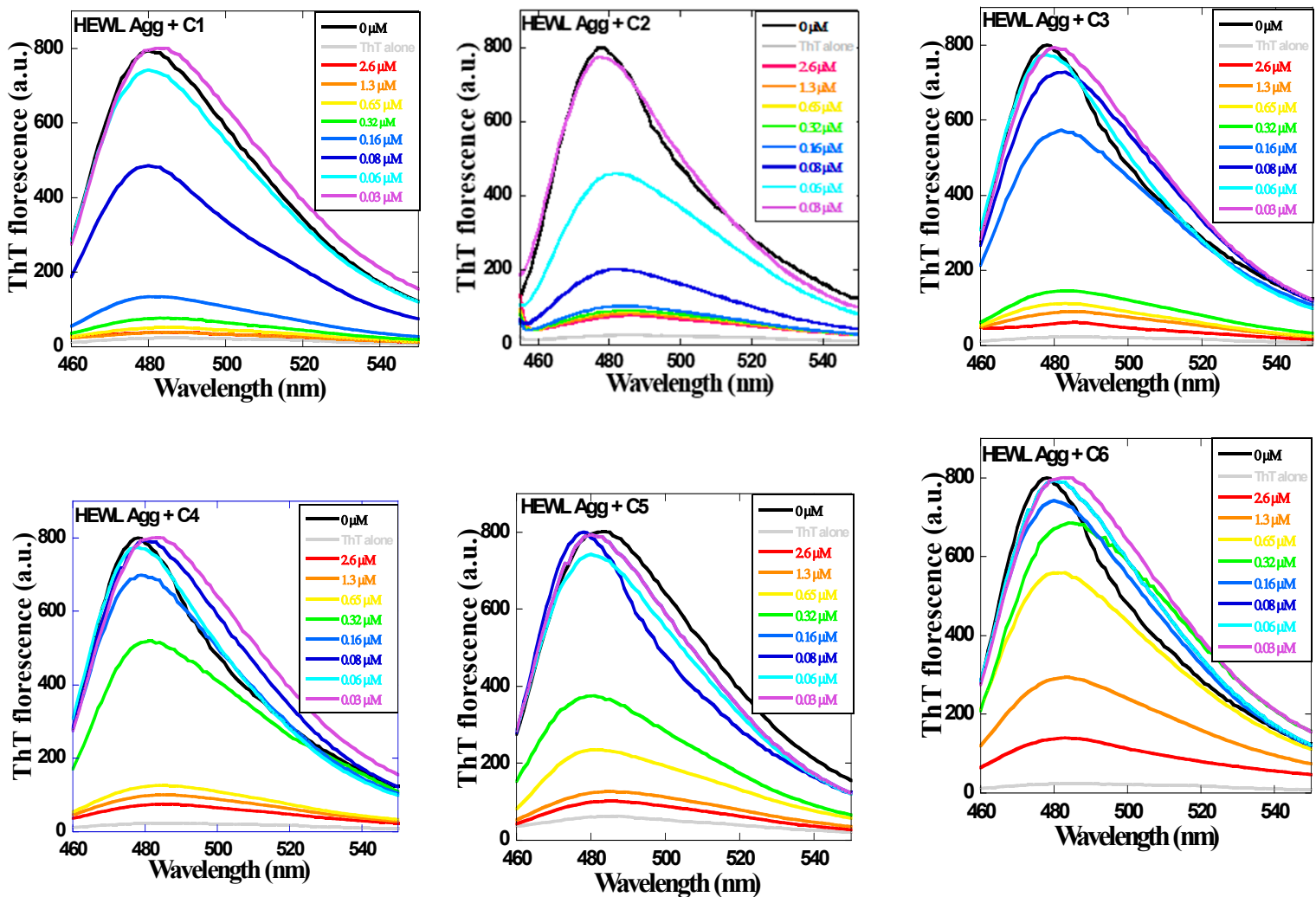

Figure 1. Dose-dependent inhibition of $0.03-2.6 \mu \mathrm{M}$ compounds 1-6 on hen egg white lysozyme (HEWL) amyloid fibril formation at $2 \mathrm{mg} / \mathrm{mL}(140 \mu \mathrm{M})$, in $50 \mathrm{mM}$ glycine buffer, $\mathrm{pH} 2.5$, and $57^{\circ} \mathrm{C}$, under stirring (250 rpm), for $48 \mathrm{~h}$, monitored by changes in thioflavin $\mathrm{T}$ (ThT) florescence intensity. The spectra refer to ThT alone (gray), HEWL pre-incubated with 0 (black), 0.03 (violet), 0.06 (indigo), 0.08 (dark blue), 0.16 (blue), 0.32 (green), 0.65 (yellow), 1.3 (orange), and 2.6 (red) $\mu \mathrm{M}$ of compounds 1-6.

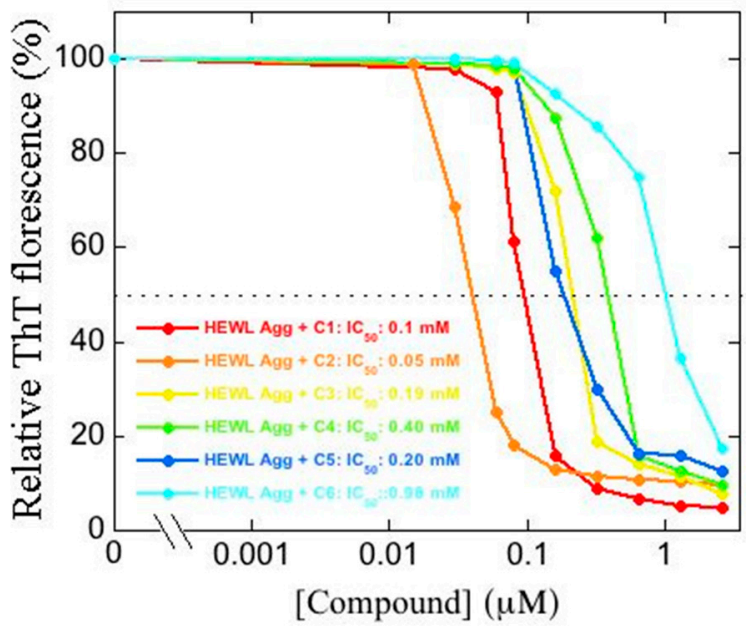

Figure 2. Concentration-dependent prevention of HEWL amyloid fibril formation by compounds 1-6 incubated as described in Figure 1 at different compound concentrations, ranging from 0.03 to $2.6 \mu \mathrm{M}$. The traces refer to compound $\mathbf{1}$ (red), compound $\mathbf{2}$ (orange), compound $\mathbf{3}$ (yellow), compound $\mathbf{4}$ (green), compound 5 (blue), and compound 6 (indigo). The dotted line indicates a level of 50\%.

A control experiment was also designed to rule out the possibility that the low ThT fluorescence intensities measured in the presence of these compounds might result from the quenching of ThT fluorescence by the compounds themselves. These compounds were separately added at final concentrations of $2.6 \mu \mathrm{M}$ to pre-formed HEWL aggregates and the ThT fluorescence assay was 
performed immediately before and after compound addition. The ThT fluorescence values were found to be similar in each case, before and after compound addition, indicating the lack of any significant quenching effect (Figure S7).

\subsection{Effect of 1,3,5-Triarylbenzenes and Their Derivatives on Heat-Induced Fibrillation of HEWL Monitored with CR Assay}

Aliquots of the same samples used for ThT experiments were also used to carry out the CR assays. The CR absorbance measured in the absence of HEWL and any of the compounds was found to be low, with a peak at $490 \mathrm{~nm}$ (Figure 3A). The CR absorbance measured in the presence of HEWL pre-incubated for $48 \mathrm{~h}$ under aggregating conditions in the absence of any compound exhibited a weak increase accompanied by a red shift of the peak to 520-540 nm (Figure 3A). The higher CR absorbance obtained in the presence of HEWL is likely to originate from the presence of protein aggregates that scatter light, whereas the red shift of the peak from 490 to 520-540 nm indicates the presence of $\beta$-sheet containing aggregates. The CR absorbance measured in the presence of HEWL pre-incubated for $48 \mathrm{~h}$ under aggregating conditions with $0.32 \mu \mathrm{M}$ compounds 1, 2, 3, 4, and 5 were found to be lower than that measured in the absence of the compounds (Figure 3A). This indicates that these compounds were able to inhibit HEWL amyloid fibril formation. The CR absorbance measured in the presence of HEWL and $0.32 \mu \mathrm{M}$ compound $\mathbf{6}$ was found to be markedly higher, with a higher red shift, indicating that this compound was not effective in inhibiting HEWL amyloid formation. These results were confirmed by analyzing the difference spectra, obtained by subtracting in each case the spectrum of CR alone from those obtained with HEWL aggregates and CR (Figure 3B). The absorbance peak at $540 \mathrm{~nm}$, obtained without compounds 1-6 and readily assigned to CR bound to the aggregates, was found to be suppressed in the presence of the various compounds 1-5, with only a modest decrease in the presence of compound 6 .

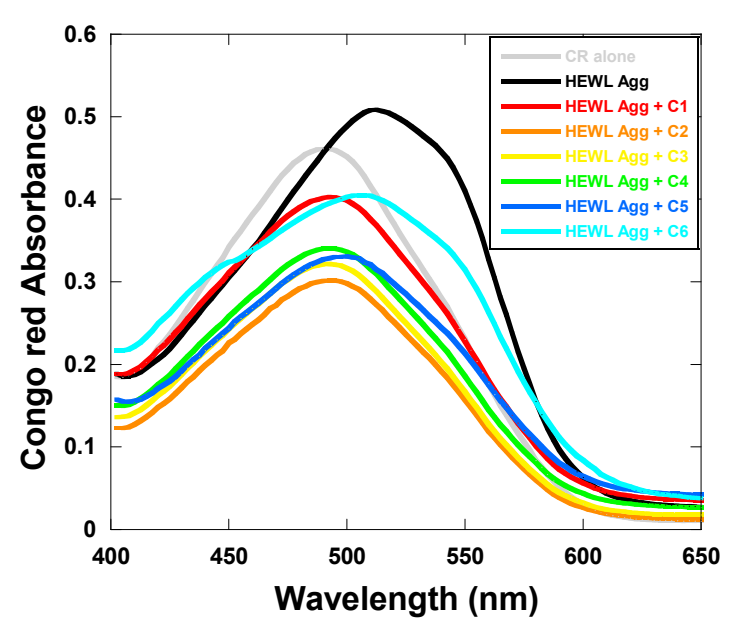

(A)

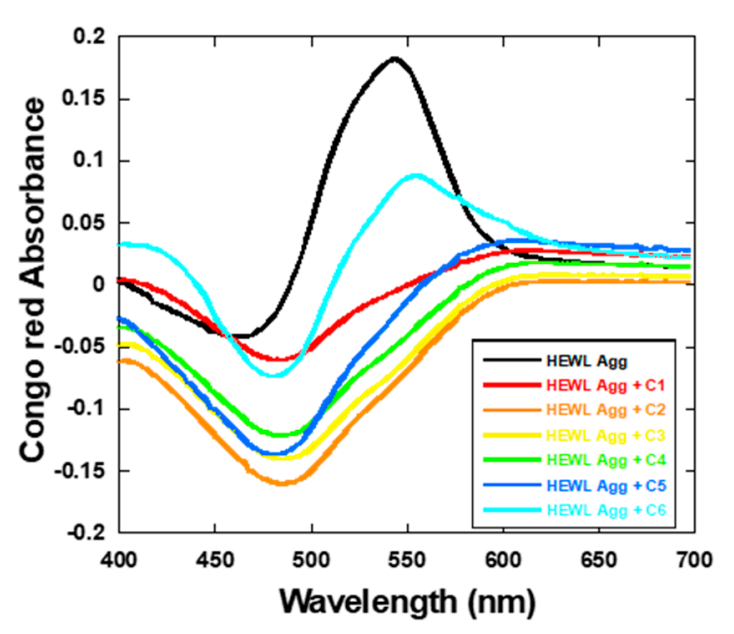

(B)

Figure 3. Effects of compounds 1-6, at a concentration of $0.32 \mu \mathrm{M}$, on HEWL aggregation at $2 \mathrm{mg} / \mathrm{mL}$, $50 \mathrm{mM}$ glycine buffer, $\mathrm{pH} 2.5,57^{\circ} \mathrm{C}$, under stirring ( $250 \mathrm{rpm}$ ), monitored by changes in $\mathrm{CR}$ absorbance after $48 \mathrm{~h}$. (A) The spectra refer to CR alone (gray), HEWL pre-incubated under aggregating conditions without compounds (black), with compound 1 (red), compound 2 (orange), compound 3 (yellow), compound 4 (green), compound 5 (blue), and compound 6 (indigo). (B) Difference spectra obtained by subtracting the spectrum of CR alone from the spectra of HEWL aggregates with CR reported in (A). Color code as in (A).

In this study, we used dimethyl sulfoxide (DMSO) for dissolving our compounds, and, thus, a control experiment was carried out to determine whether DMSO itself had an effect on the HEWL 
aggregation. However, $2 \%(v / v)$ DMSO used here has a minimal effect on the aggregation of HEWL (Figure S8). Therefore, all compounds were dissolved in DMSO prior to use.

The results observed by the ThT and CR assay depicted in Figures 1-3 could be due to an ability of the six compounds to inhibit HEWL aggregation. Alternatively, they might just inhibit amyloid fibril formation without preventing the formation of protein aggregates with a non-amyloid structure. To assess either possibility, we centrifuged the various HEWL samples and measured the protein concentration of the resuspended pellets, showing that pellets obtained from samples preincubated with compounds 1-6 had a higher protein content than those incubated without compounds. This indicated that the aromatic molecules did not inhibit aggregation of HEWL generally, but more specifically its process of amyloid fibril formation.

\subsection{Effect of 1,3,5-Triarylbenzenes and Their Derivatives on Heat-Induced Fibrillation of HEWL Monitored with FTIR Spectroscopy}

New samples of HEWL aggregates with or without compounds 1-6 at a concentration of $0.32 \mu \mathrm{M}$ were prepared, under the same conditions as those used for ThT and CR experiments, centrifuged after $48 \mathrm{~h}$ to collect the aggregates, resuspended at high concentration in $\mathrm{D}_{2} \mathrm{O}$ and analyzed with FTIR spectroscopy, to determine the effects of the six compounds on the secondary structure of the HEWL aggregates. The HEWL aggregates without compounds showed a clear maximum at $1624 \pm 1 \mathrm{~cm}^{-1}$ in the amide I region of the FTIR spectrum, which can readily be assigned to intermolecular $\beta$-sheet structure (Figure 4). Another peak is present at ca. $1650 \mathrm{~cm}^{-1}$ attributable to either unordered or $\alpha$-helical secondary structure. All the HEWL aggregates formed in the presence of the compounds showed a lower absorbance peak at $1623-1625 \mathrm{~cm}^{-1}$ and a higher absorption at $1648-1652 \mathrm{~cm}^{-1}$, indicating loss of $\beta$-sheet structure and gain of other types of secondary structure in the aggregates (Figure 4). In particular, compound $\mathbf{2}$ led to the most remarkable change, followed by compound $\mathbf{1}$, compound 4, compound 3, compound 5, and compound 6, a ranking similar to that observed with ThT fluorescence.

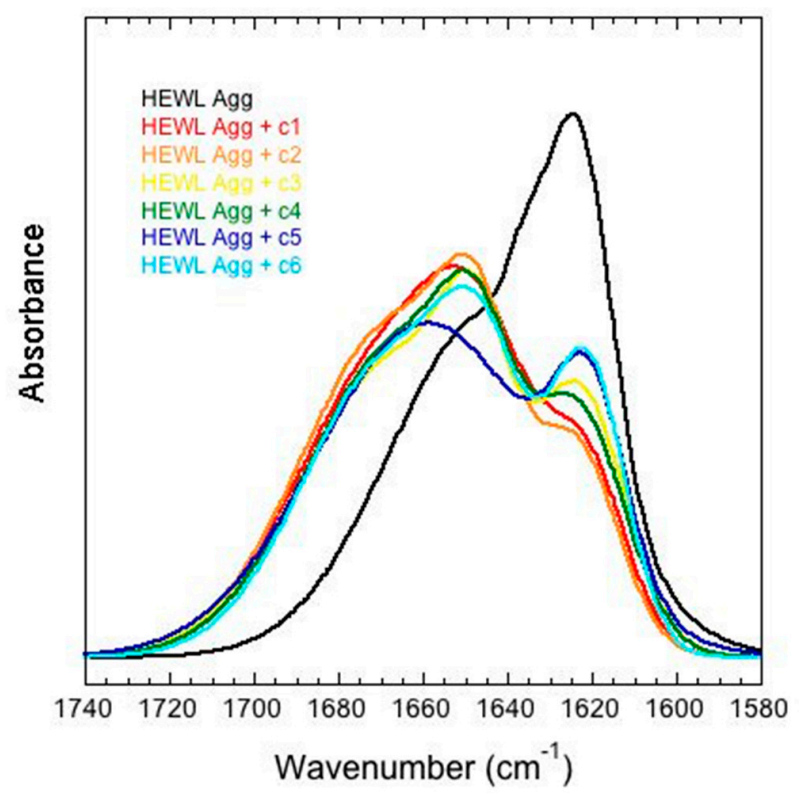

Figure 4. Inhibitory effects of the compounds 1-6 on the formation of $\beta$-sheet secondary structure of HEWL monitored by FTIR. HEWL amyloid fibril formation was pre-incubated at $2 \mathrm{mg} / \mathrm{mL}(140 \mu \mathrm{M})$,

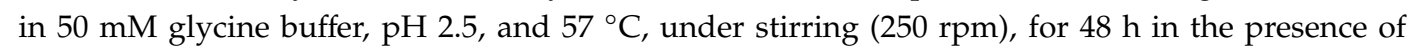
$0.32 \mu \mathrm{M}$ compounds 1-6, centrifuged at $13,000 \times g$ for $10 \mathrm{~min}$ and resuspended in $\mathrm{D}_{2} \mathrm{O}$ to a final HEWL concentration of $27.8 \mathrm{mg} / \mathrm{mL}$. Blank-subtracted, baseline-corrected, and normalized FTIR spectra (amide I region) of HEWL aggregates without (black) or with compound $\mathbf{1}$ (red), compound $\mathbf{2}$ (orange), compound 3 (yellow), compound 4 (green), compound 5 (blue), and compound 6 (indigo). 


\subsection{Effect of the Compounds on the Kinetic of HEWL Aggregation}

The time course of HEWL amyloid fibril formation in the absence of the compounds monitored by measuring the ThT fluorescence emission intensity over a period of $48 \mathrm{~h}$ was nucleation dependent, with a typical sigmoidal profile, including lag, exponential, and equilibrium phases [8]. This kinetic trace was meant to be qualitative rather than quantitative and, for this reason, data were acquired only every $6 \mathrm{~h}$ until $48 \mathrm{~h}$. Inhibition of amyloid aggregation by the various inhibitors is generally quantified by assessing changes of the lag time, exponential phase, and aggregation extent at equilibrium plateau. The lag times measured in the presence of compounds $1-5$, thus except compound 6 , was relatively long (Figure 5). In addition, in presence of all compounds, again except compound 6, the exponential phase changed but with different magnitudes (Figure 5).

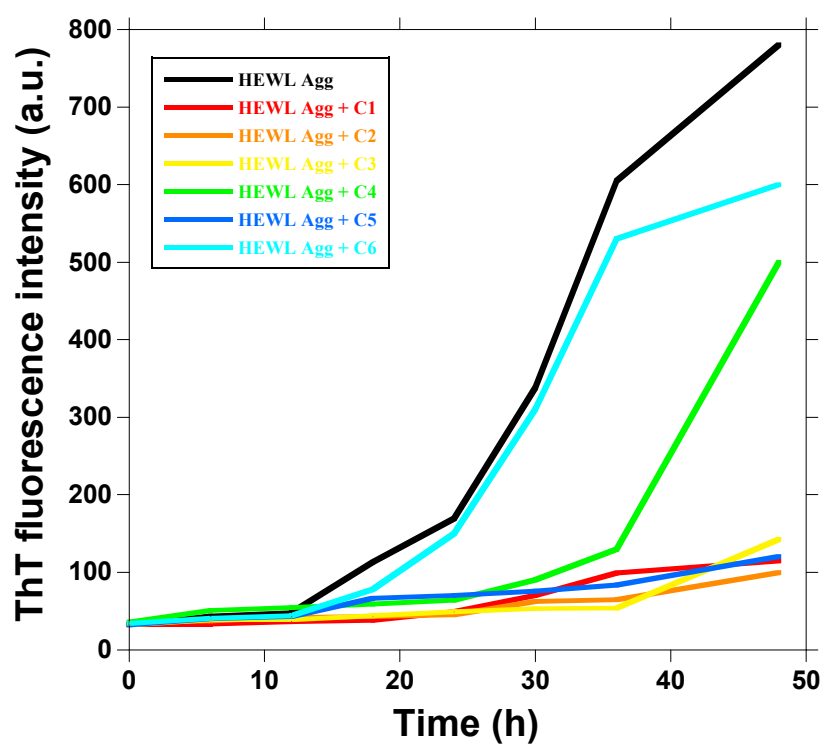

Figure 5. Kinetics of HEWL aggregation at $2 \mathrm{mg} / \mathrm{mL}(140 \mu \mathrm{M})$, in $50 \mathrm{mM}$ glycine buffer, $\mathrm{pH} 2.5,57^{\circ} \mathrm{C}$, under stirring ( $250 \mathrm{rpm}$ ), in the presence of $0.32 \mu \mathrm{M}$ of compounds $\mathbf{1}-\mathbf{6}$ followed by monitoring ThT fluorescence intensity. The kinetic traces refer to HEWL without compounds (black), HEWL with compound 1 (red), HEWL with compound 2 (orange), HEWL with compound 3 (yellow), HEWL with compound 4 (green), HEWL with compound 5 (blue), and HEWL with compound 6 (indigo).

\subsection{Effect of the Compounds on HEWL Aggregation Morphology}

In order to define further the nature of the aggregated species, an analysis of their morphologies was carried out using AFM. HEWL was incubated under the same aggregation conditions used for the ThT, CR, and FTIR experiments, i.e., for $48 \mathrm{~h}$ at a concentration of $2 \mathrm{mg} / \mathrm{mL}(140 \mu \mathrm{M})$ in $50 \mathrm{mM}$ glycine buffer, $\mathrm{pH} 2.5$, and $57^{\circ} \mathrm{C}$, under stirring $(250 \mathrm{rpm}$ ), in the absence or presence of $0.32 \mu \mathrm{M}$ of compounds 1-6 and the resulting samples were examined by AFM (Figure 6). HEWL aggregates in the absence of compounds showed typical long, unbranched fibrils. On the other hand, when HEWL was incubated in presence of compounds 1-4, very few fibrils were observed after $48 \mathrm{~h}$. Rather, oligomeric and/or amorphous species were predominant. HEWL pre-incubated in presence of compound $\mathbf{5}$ showed a few short fibrillar assemblies along with oligomeric species and, in the presence of compound $\mathbf{6}$, a mixture of unbranched filamentous assemblies appeared. These results again showed that compound 6 cannot inhibit the formation of HEWL aggregates in agreement with the ThT and CR results.

\subsection{Effect of the Compounds on HEWL Amyloid Induced Cytotoxicity}

We then assessed the cytotoxicity of HEWL aggregates, formed in the absence or presence of compounds 1-6, according to the aggregation protocol described for the ThT experiments. HEWL aggregates were collected by centrifugation, dried under $\mathrm{N}_{2}$, dissolved in cell culture medium, and 
added to SH-SY5Y human neuroblastoma cells at a concentration of $2 \mu \mathrm{M}$ (monomer equivalents). The ability of the resulting aggregates to cause cellular dysfunction was assessed by performing the MTT reduction inhibition assay, a widely used indicator of mitochondrial dysfunction [45]. The ability of SH-SY5Y cells to reduce MTT was significantly decreased to $73.9 \pm 2.1 \%$ (relative to untreated cells) after a $24 \mathrm{~h}$ exposure to HEWL aggregates, whereas it was unaffected by native HEWL treatment (Figure 7A). The ability of cells to reduce MTT was significantly increased when HEWL aggregates were formed in the presence of compound 1 (to $92.7 \pm 3.2 \%$ ), 2 (to $96.2 \pm 3.2 \%$ ) and 5 (to $93.9 \pm 2.9 \%$ ). By contrast, incubation with compounds 3, 4, and 6 resulted in a partial rescue of the cell viability. Very similar results were obtained by measuring the activity of caspase-3, a well-recognized apoptotic marker [46]. A significant activation of caspase-3 ( $320 \pm 12 \%$, as compared to untreated cells) was observed following treatment for $24 \mathrm{~h}$ of SH-SY5Y cells with HEWL aggregates at $2 \mu \mathrm{M}$ (Figure 7B). Moreover, the presence of compounds 1, 2, 4, and 5 during HEWL aggregation significantly prevented the apoptotic response induced by aggregates (Figure 7B). Furthermore, in this case, compounds 3 and 6 generated only a slight protective effect on apoptotic pathway activation.

HEWL Agg without compounds

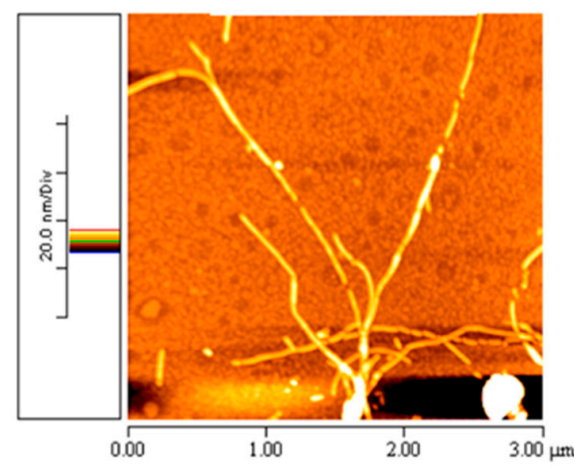

HEWL Agg + C1

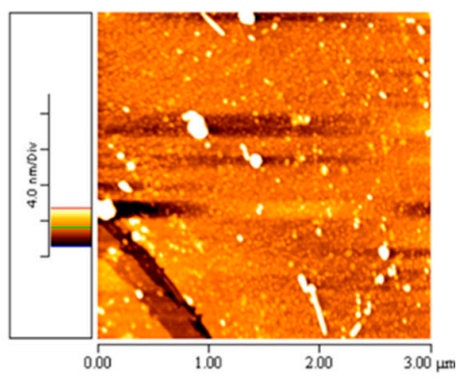

HEWL Agg + C4

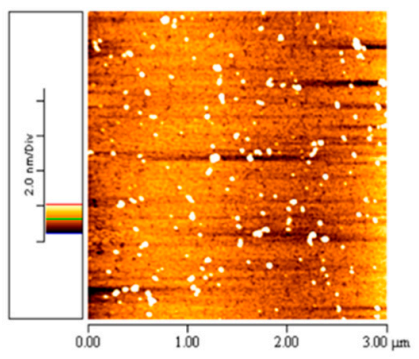

HEWL Agg + C2

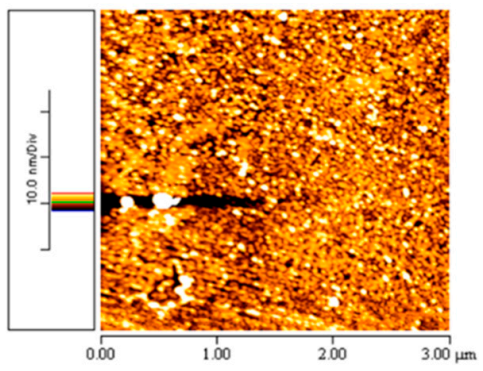

HEWL Agg + C5

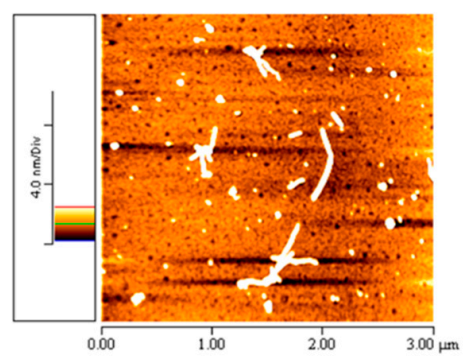

HEWL Agg + C3

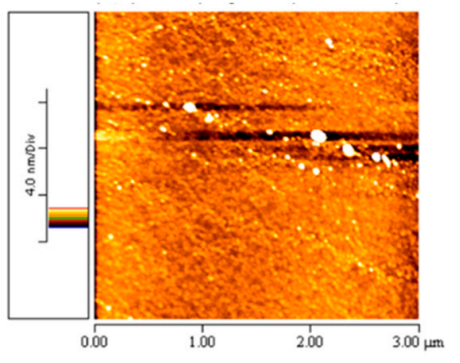

HEWL Agg + C6

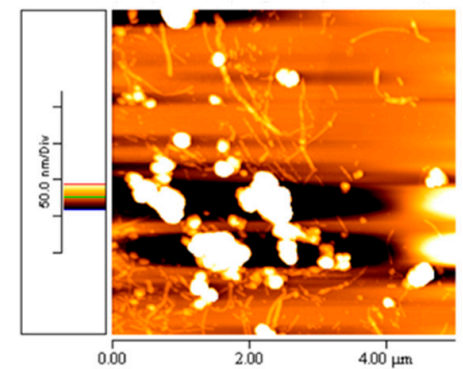

Figure 6. Atomic force microscopy (AFM) images of HEWL aggregates formed in absence or presence of compounds 1-6. HEWL was pre-incubated under conditions promoting amyloid fibril formation that is $48 \mathrm{~h}$ at a concentration of $140 \mu \mathrm{M}$, in $50 \mathrm{mM}$ glycine buffer, $\mathrm{pH} 2.5,57^{\circ} \mathrm{C}$, under stirring $(250$ rpm), in the absence or presence of $0.32 \mu \mathrm{M}$ compounds 1-6. 
A

B
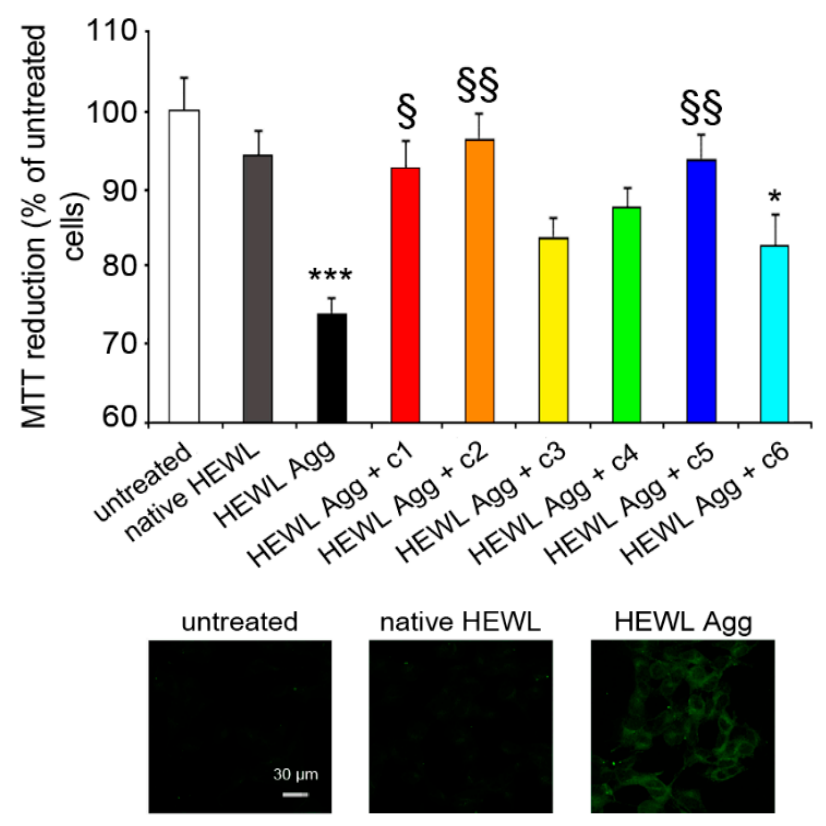

native HEWL

HEWL Agg

HEWL Agg + c1 HEWL Agg + c2 HEWL Agg + c3
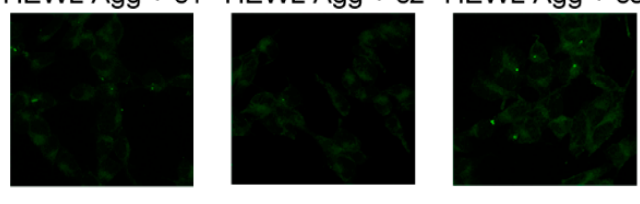

HEWL Agg + c4 HEWL Agg + c5 HEWL Agg + c6
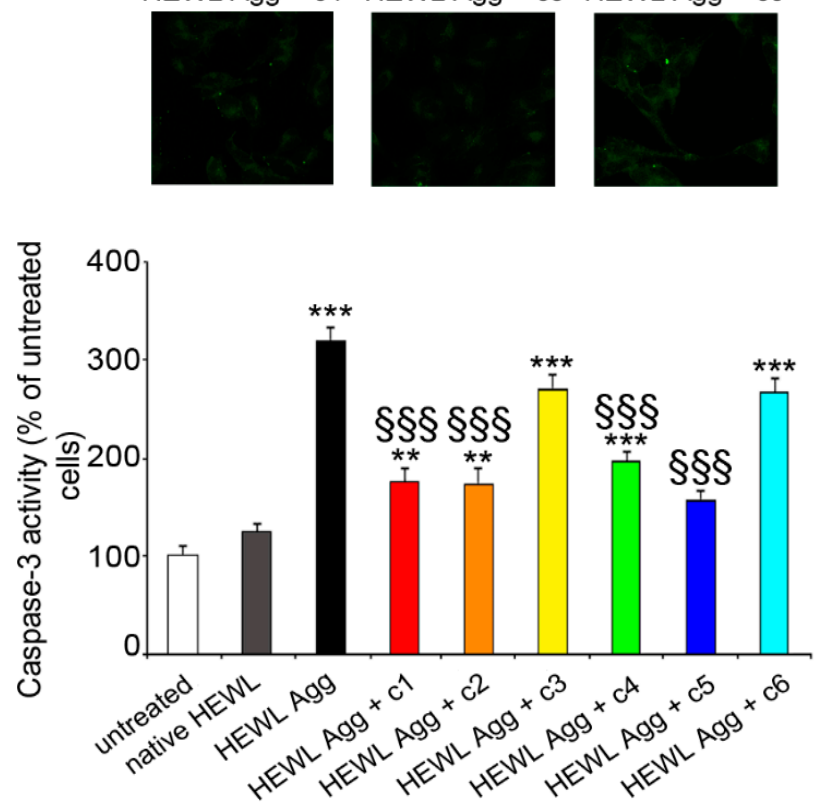

Figure 7. Impairment of cell viability after exposure to HEWL aggregates. (A) MTT reduction in SH-SY5Y cells treated for $24 \mathrm{~h}$ with $2 \mu \mathrm{M}$ (monomer equivalents) HEWL aggregates formed in the absence or presence of the indicated compounds. (B) Caspase-3 activity in SH-SY5Y cells treated for $24 \mathrm{~h}$ with $2 \mu \mathrm{M}$ HEWL aggregates formed in the absence or presence of the indicated compounds. The green fluorescence arises from intracellular caspase- 3 activity. The results of a semi-quantitative analysis of the caspase-3-derived fluorescence data are expressed as the percentage of the value for untreated cells. In both panels, experimental errors are standard error of mean (S.E.M). Samples were analyzed by one-way ANOVA followed by Bonferroni's multiple comparison test relative to untreated cells $\left({ }^{*} p<0.05,{ }^{* *} p<0.01,{ }^{* * *} p<0.001\right)$, or to cells treated with HEWL aggregates in the absence of compounds ( $\$<0.05, \S \S p<0.01$, §§§ $p<0.001)$. 


\section{Discussion}

Design and synthesis of novel small-compound inhibitors of the process of amyloid fibril formation is one of the leading therapeutic approaches for the treatment of amyloid diseases [47-50]. The studies on different amyloidogenic proteins showed that small aromatic compounds are able to inhibit fibril formation, possibly due to their ability to interfere with the $\beta$-sheet architecture of the fibrils and/or aromatic stacking in fibril stabilization [22,30,51,52]. In fact, the exact contribution of aromaticity to amyloid formation is controversial and remains under debate [53].

Various findings demonstrate that the functional groups appended to the aromatic rings [54,55], geometry and steric profile of the functional groups on the aromatic rings [53], and also number of rings [36] can dramatically affect amyloid formation. We have recently reported that bis(indolyl)phenylmethane compounds inhibited the formation of amyloid fibrils and associated toxicity in a concentration-dependent manner [33]. We also showed that all tested compounds were able to inhibit HEWL amyloid fibril formation but with different efficiencies, which showed the importance of slight variations of the functional groups within the same scaffold as a small molecule [33].

In this work, a series of novel 1,3,5-triarylbenzenes derivatives having four aromatic rings and different electron-donor or -acceptor substitutions were synthesized and evaluated for their potential to prevent HEWL amyloid aggregation. These compounds, similar to bis(indolyl)phenylmethanes studied previously, were shown to inhibit HEWL amyloid fibril formation under conditions in which the protein is initially partially unfolded, but with different magnitude. In particular, considering the various techniques used here, including the ThT and CR assays, AFM, and FTIR, compounds 1-3 were found to be clearly more effective as inhibitors in comparison to compounds 4-6, particularly the latter that did not show any detectable effect (Figures 1-5). These findings showed that electron-donating substituents have less efficacy in preventing HEWL amyloid formation, whereas electron-withdrawing groups have much more influence in amyloid inhibition. The $\mathrm{IC}_{50}$ values of the compounds were between 0.05 and $0.98 \mu \mathrm{M}$, which are two orders of magnitude lower than the $\mathrm{IC}_{50}$ value measured by a representative bis(indolyl)phenylmethane, i.e., $12.3 \pm 1 \mu \mathrm{M}$ [33].

The amorphous and unstructured HEWL aggregates formed in the presence of all compounds were less toxic than the HEWL fibrils formed in their absence, as shown by MTT cell viability and caspase activity assays (Figure 7). Moreover, our results showed that HEWL aggregates formed in the presence of 1,3,5-triarylbenzenes derivatives, similar to results obtained with bis(indolyl)phenylmethane [33] and curcumin [56] derivatives, were non-toxic or retain a weak toxicity, allowing all these compounds to be classified as class I molecules, based on the classification proposed by Ladiwala et al., i.e., molecules that remodel soluble oligomers into species (often large off-pathway aggregates) that are non-toxic [57].

It has been proposed that $\pi-\pi$ stacking of aromatic rings can be enhanced when two rings are electron poor and rich, respectively [36]. Our work and results presented by other scientists [36] are in agreement with this theory, as the addition of a strong electron-withdrawing group, such as $-\mathrm{NO}_{2},-\mathrm{F}$, or $-\mathrm{CN}$ [36] on the aromatic inhibitor increases the inhibitory effect, possibly due to the formation of a strong electron donor-electron acceptor complex between the inhibitory compounds and the aromatic residues of HEWL. In particular, the -F group was found to be the most effective, probably due to its high electronegativity, followed by the $-\mathrm{NO}_{2}$ group. On the other hand, when an electron-donating group, such as a $-\mathrm{OH},-\mathrm{CH}_{3}$, or $-\mathrm{OCH}_{3}$, was added, amyloid inhibition is decreased due to a repulsion between the electron-rich aromatic ring of the inhibitor and the electron-rich aromatic residues of HEWL, which does not allow the establishment of a stable complex between the inhibitor and the protein undergoing aggregation. In this context, the - $\mathrm{OH}$ group is the least effective in inhibiting HEWL aggregation.

Inhibitory effects of bis(indolyl)phenylmethanes may be discussed from different points of view, including different factors, such as the importance of inter- and intra-molecular hydrogen bonds, electronic effects and steric hindrances, the intrinsic steric congestion originating from the structural framework of bis-indolylarylmethanes, all affected by the substituents. In the case of 
1,3,5-triarylbenzenes, a fully planar formula presents three aryl substituents in the same plane as the central benzene ring. In this case, only the aryl substituents may exert a little steric congestion around the aryl rings. Therefore, the net structure should have a planar identity and we can assume an effective diffusion of these types of compounds into amyloid fibrils. This can explain both the most effective inhibitory potential of 1,3,5-triarylbenzenes relative to bis-indolylarylmethanes and the critical role played by the electron releasing/donating substituents on the aryl rings in determining such an inhibition.

\section{Materials and Methods}

\subsection{Materials}

Hen egg white lysozyme (HEWL), thioflavin T (ThT), and Congo red (CR) were purchased from Sigma-Aldrich (St. Louis, MO, USA). Other reagents were purchased from Merck (Darmstadt, Germany), unless stated otherwise. All synthesized molecules were compared, in terms of their spectral and physical data, with those reported previously [58].

\subsection{General Chemistry}

All reagents and starting materials were commercially available and were used as received. Natural clinoptilolite-rich tuffs were obtained from the Sabzevar region in the north-east of Iran. Fourier-transform infrared (FT-IR) spectra were recorded on a 8700 Shimadzu Fourier-transform spectrophotometer (Shimadzu, Tokyo, Japan) in the region of $400-4000 \mathrm{~cm}^{-1}$ using $\mathrm{KBr}$ pellets. ${ }^{1} \mathrm{H}$ and ${ }^{13} \mathrm{C}$ NMR spectra were recorded on a Bruker AVANCE $300 \mathrm{MHz}$ instrument (Bruker, MA, USA) using TMS as internal reference. All products were identified by comparison of their spectral and physical data with those previously reported. Wells-Dawson diphosphooctadecatungstic acid $\mathrm{H}_{6} \mathrm{P}_{2} \mathrm{~W}_{18} \mathrm{O}_{62} \cdot 24 \mathrm{H}_{2} \mathrm{O}$ was prepared according to the literature method [59].

General Procedure for the Conversion of Acetophenone into 1,3,5-Triphenylbenzene

In a typical reaction, acetophenone $(1 \mathrm{mmoL})$ and the surface-modified HPA/NCP $(15 \mathrm{mg})$ were added to a small test tube and the reaction mixture was stirred for $2.5 \mathrm{~h}$ at $100{ }^{\circ} \mathrm{C}$. After completion of the reaction, as indicated by thin layer chromatography (TLC), the reaction mass was cooled to $25^{\circ} \mathrm{C}$; then, hot ethanol was added to the reaction mixture and the mixture was stirred for $5 \mathrm{~min}$. The insoluble catalyst was isolated via simple filtration. The filtrate containing water as the only byproduct of the cyclotrimerization was concentrated under reduced pressure, and finally the obtained crude product was purified through re-crystallization in $\mathrm{EtOH}: \mathrm{H}_{2} \mathrm{O}(3: 1)$ as confirmed by an intense single spot in TLC. The pure products were specified based on the spectral data and determination of their melting points.

\section{1,3,5-Triphenylbenzene (Compound $\mathbf{1}$ )}

Light yellow solid; m. p. $171-173{ }^{\circ} \mathrm{C}$. IR (KBr): $\mathrm{v}_{\max }=3053,1651,1494,1431,1125,758,700 \mathrm{~cm}^{-1}$. ${ }^{1} \mathrm{H}$ NMR (DMSO-d $\left.\mathrm{D}_{6}, 500 \mathrm{MHz}\right): \delta 7.88(\mathrm{~s}, 3 \mathrm{H}), 7.87-7.86(\mathrm{~m}, 6 \mathrm{H}), 7.52-7.49(\mathrm{t}, \mathrm{J}=7.5 \mathrm{~Hz}, 6 \mathrm{H}), 7.43-7.40$ $(\mathrm{t}, \mathrm{J}=7.5 \mathrm{~Hz}, 3 \mathrm{H}) .{ }^{13} \mathrm{C}$ NMR (DMSO-d 6 , $\left.125 \mathrm{MHz}\right): \delta 141.6,140.1,128.9,127.7,127.2,124.4$.<smiles>c1ccc(-c2cc(-c3ccccc3)cc(-c3ccccc3)c2)cc1</smiles> 


\section{1,3,5-Tris(4-Fluorophenyl)Benzene (Compound 2)}

White solid; m. p. $238-240{ }^{\circ} \mathrm{C}$. IR (KBr): $\mathrm{v}_{\max }=3059,1604,1508,1449,1224,1159,825,771 \mathrm{~cm}^{-1}$. ${ }^{1} \mathrm{H} \mathrm{NMR}\left(\mathrm{CDCl}_{3}, 500 \mathrm{MHz}\right): \delta 7.67(\mathrm{~s}, 3 \mathrm{H}), 7.61(\mathrm{~d}, \mathrm{~J}=8.5 \mathrm{~Hz}, 6 \mathrm{H}), 7.59(\mathrm{~d}, \mathrm{~J}=8.5 \mathrm{~Hz}, 6 \mathrm{H}) .{ }^{13} \mathrm{C} \mathrm{NMR}$ $\left(\mathrm{CDCl}_{3}, 125 \mathrm{MHz}\right): 161.7,137.6,132.4,129.0(\mathrm{~d}, \mathrm{~J}=7.5 \mathrm{~Hz}), 125.3,115.9(\mathrm{~d}, \mathrm{~J}=22.5 \mathrm{~Hz})$.

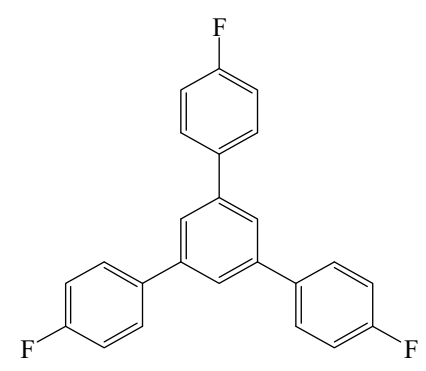

\section{1,3,5-Tris(4-Nitrophenyl)Benzene (Compound 3)}

White solid; m. p. $151-152^{\circ} \mathrm{C}$. IR (KBr): $\mathrm{v}_{\max }=3043,1595,1489,1379,1085,1007,849 \mathrm{~cm}^{-1} .{ }^{1} \mathrm{H}$ $\operatorname{NMR}\left(\mathrm{CDCl}_{3}\right): \delta=7.56(\mathrm{~d}, \mathrm{~J} 8.1 \mathrm{~Hz}, 6 \mathrm{H}), 7.62(\mathrm{~d}, \mathrm{~J} 8.2 \mathrm{~Hz}, 6 \mathrm{H}), 7.70(\mathrm{~s}, 3 \mathrm{H}) .{ }^{13} \mathrm{C} \mathrm{NMR}\left(125 \mathrm{MHz}, \mathrm{CDCl}_{3}\right)$ : $\delta 122.3,125.0,128.9,132.1,139.7,141.6$.

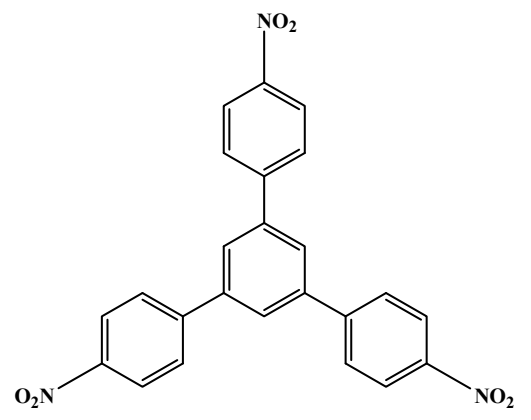

\section{1,3,5-Tris(4-Methylphenyl)Benzene (Compound 4)}

White solid; m. p. $178-179{ }^{\circ} \mathrm{C}$. IR (KBr): $\mathrm{v}_{\max }=3017,2922,1612,1511,1491,1109,812 \mathrm{~cm}^{-1} \cdot{ }^{1} \mathrm{H}$ NMR $\left(\mathrm{CDCl}_{3}, 500 \mathrm{MHz}\right): \delta 7.74(\mathrm{~s}, 3 \mathrm{H}), 7.62(\mathrm{~d}, \mathrm{~J}=8.0 \mathrm{~Hz}, 6 \mathrm{H}), 7.30(\mathrm{~d}, \mathrm{~J}=7.5 \mathrm{~Hz}, 6 \mathrm{H}), 2.44(\mathrm{~s}, 9 \mathrm{H}) .{ }^{13} \mathrm{C}$ NMR ( $\left.\mathrm{CDCl}_{3}, 125 \mathrm{MHz}\right): 142.2,138.3,137.4,129.4,127.3,124.7,21.1$.

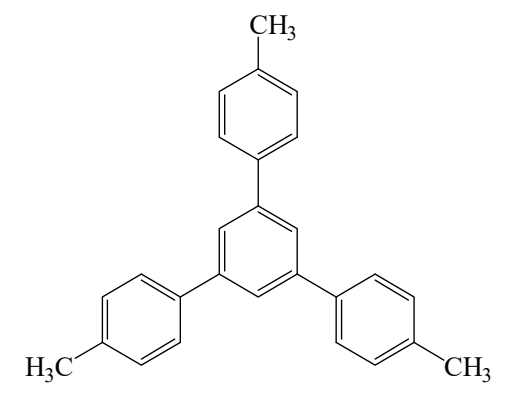

\section{1,3,5-Tris(4-Methoxyphenyl)Benzene (Compound 5)}

White solid; m. p. $142-143{ }^{\circ} \mathrm{C} . \mathrm{IR}(\mathrm{KBr}): \mathrm{v}_{\max }=2953,2918,2848,1598,1460,1378,1263,1097$, $802 \mathrm{~cm}^{-1} .{ }^{1} \mathrm{H} \mathrm{NMR}\left(\mathrm{CDCl}_{3}, 500 \mathrm{MHz}\right): \delta 7.59(\mathrm{~d}, \mathrm{~J}=9.0 \mathrm{~Hz}, 6 \mathrm{H}), 7.37(\mathrm{~s}, 3 \mathrm{H}), 6.99(\mathrm{~d}, \mathrm{~J}=8.5 \mathrm{~Hz}, 6 \mathrm{H})$, 3.86 (s, 9H). ${ }^{13} \mathrm{C} \mathrm{NMR}\left(\mathrm{CDCl}_{3}, 125 \mathrm{MHz}\right): 159.7,141.7,134.0,129.3,122.7,114.2,55.9$. 
<smiles>COc1ccc(-c2cc(-c3ccc(OC)cc3)cc(-c3ccc(OC)cc3)c2)cc1</smiles>

\section{1,3,5-Tris(4-Hydroxyphenyl)Benzene (Compound 6)}

White solid; m. p. $237-239^{\circ} \mathrm{C}$. IR (KBr): $\mathrm{v}_{\max }=2953,2918,2848,1606,1460,1378,1263,1097$, $802 \mathrm{~cm}^{-1} .{ }^{1} \mathrm{H}$ NMR $\left(\mathrm{CDCl}_{3}\right): \delta=3.81(\mathrm{~s}, 9 \mathrm{H}), 6.94-7.41(\mathrm{~m}, 12 \mathrm{H}), 7.79(\mathrm{~s}, 3 \mathrm{H}) .{ }^{13} \mathrm{C} \mathrm{NMR}\left(\mathrm{CDCl}_{3}\right.$, $125 \mathrm{MHz}): \delta 55.4,114.3,123.8,128.3,133.9,141.8,159.3$.<smiles>Oc1ccc(-c2cc(-c3ccc(O)cc3)cc(-c3ccc(O)cc3)c2)cc1</smiles>

\subsection{Protein Aggregation}

HEWL concentration was determined by optical absorption at $280 \mathrm{~nm}\left(\varepsilon_{280}=2.65 \mathrm{~L} \cdot \mathrm{g}^{-1} \cdot \mathrm{cm}^{-1}\right)[60]$. HEWL was dissolved to a concentration of $2 \mathrm{mg} / \mathrm{mL}(140 \mu \mathrm{M})$ in $50 \mathrm{mM}$ glycine buffer, $\mathrm{pH} 2.5$, centrifuged for $10 \mathrm{~min}$ at $13,000 \mathrm{rpm}$, then incubated at $57^{\circ} \mathrm{C}$ for the specified time lengths in the absence or presence of the indicated concentrations of compounds 1-6, under gentle stirring at $250 \mathrm{rpm}$ by a Teflon magnetic bar [33].

\subsection{ThT Fluorescence Assay}

A mother solution of $2.5 \mathrm{mM}$ ThT was prepared in $10 \mathrm{mM}$ sodium phosphate buffer, $150 \mathrm{mM}$ $\mathrm{NaCl}, \mathrm{pH}$ 7.0. It was then passed through a $0.45 \mu \mathrm{m}$ filter paper and stored at $4{ }^{\circ} \mathrm{C}$ until it was placed at room temperature immediately before use. At regular time intervals, a $10 \mu \mathrm{L}$ aliquot of protein solution was mixed with $990 \mu \mathrm{L}$ of ThT solution in a $10 \times 10 \mathrm{~mm}$ quartz cuvette and the fluorescence emission spectra were recorded at room temperature using a Cary Eclipse VARIAN fluorescence spectrophotometer (Varian, Mulgrave, Australia) and an excitation wavelength of $440 \mathrm{~nm}$ [61].

\subsection{CR Assay}

Since compounds 1-6 have optical absorption spectra partially overlapped to that of CR, all protein samples were centrifuged at 10,000 rpm and the pellets resuspended in $50 \mathrm{mM}$ glycine buffer, $\mathrm{pH} 2.5$, at room temperature. A mother solution of $20 \mathrm{mMCR}$ was prepared in $5 \mathrm{mM}$ sodium phosphate buffer, $150 \mathrm{mM} \mathrm{NaCl}, \mathrm{pH} 7.4$, it was then filtered using a center-glass $\mathrm{N} 4$ filter and stored at $4{ }^{\circ} \mathrm{C}$, until it was placed at room temperature immediately before use. At different time points during protein aggregation, a $60 \mu \mathrm{L}$ aliquot of resuspended protein solution was mixed with $440 \mu \mathrm{L}$ of CR solution. Optical absorption spectra were acquired after $2-3$ min equilibration at $25^{\circ} \mathrm{C}$, using a Cecil 7200 UV-visible spectrophotometer (Aquarius, Cambridge, England) and a $1 \mathrm{~cm}$ path-length cell. 


\subsection{FTIR Spectroscopy}

Samples were incubated for $48 \mathrm{~h}$ to promote aggregation as described above in the presence of $0.32 \mu \mathrm{M}$ compounds 1-6, centrifuged at $13,000 \times g$ for $10 \mathrm{~min}$ and resuspended in $\mathrm{D}_{2} \mathrm{O}$ to a final volume of $72.8 \mu \mathrm{L}$, to reach a final concentration of $27.8 \mathrm{mg} / \mathrm{mL}$. For each sample, $40 \mu \mathrm{L}$ was deposited onto an Omni-Cell transmission cell with a $25 \mu \mathrm{m}$ spacer (Specac, Orpington, UK), and Fourier-transform infrared (FTIR) spectra were recorded using a FTS-40 FTIR spectrometer (Bio-Rad, Hercules, CA, USA) purged with a continuous flow of dry air. Sixty-four interferograms were accumulated in each case at a spectral resolution of $1 \mathrm{~cm}^{-1}$. The FTIR absorbance spectra were blank-subtracted and baseline-corrected to reveal the amide I region $\left(1600-1700 \mathrm{~cm}^{-1}\right)$. For each spectrum, the sharp water peaks in the amide I and flanking regions $\left(1580-1800 \mathrm{~cm}^{-1}\right.$ ) were eliminated by using a multiple Gaussian function to fit only the experimental data that were devoid of such peaks in this region and replotting the spectrum as the best fitted function. All spectra were normalized to the same amide I region area. Additional smoothing was not carried out.

\subsection{Atomic Force Microscopy}

HEWL samples pre-incubated for $48 \mathrm{~h}$ under aggregating conditions with or without $0.32 \mu \mathrm{M}$ compounds 1-6 were diluted 100 times in filtered deionized water. A $5 \mu \mathrm{L}$ aliquot of each of the resulting samples was placed on freshly cleaved mica at room temperature. After a few minutes, the mica was slowly washed with $100 \mu \mathrm{L}$ of deionized water and dried with $\mathrm{N}_{2}$. Each image was acquired in a non-contact mode at a scan speed of $30 \mu \mathrm{m} / \mathrm{s}$, loop filter of $3 \mathrm{~Hz}$ and force of $200 \mathrm{nN}$ with a Dual Scope Probe Scanner (Veeco, model Auto probe, CP-Research, CA, USA) with an area of $5 \times 5 \mu \mathrm{m}^{2}$. Conical shape silicon tips (MikroMasch NSC16) with a resonance frequency of $150 \mathrm{kHz}$ and a nominal constant of $40 \mathrm{~N} / \mathrm{m}$ were used. Fifteen images were collected for each compound.

\subsection{Cell Cultures}

Authenticated human neuroblastoma SH-SY5Y cells were purchased from American Type Culture Collection (ATCC) (Manassas, VA, USA) and they tested negative for mycoplasma contaminations. SH-SY5Y cells were cultured in Dulbecco's modified Eagle's medium (DMEM), F-12 Ham with 25 mM HEPES and $\mathrm{NaHCO}_{3}$ (1:1) supplemented with $10 \%$ fetal bovine serum (FBS), $1.0 \mathrm{mM}$ glutamine and $1.0 \%$ penicillin and streptomycin solution. Cells were maintained in a $5.0 \% \mathrm{CO}_{2}$ humidified atmosphere at $37^{\circ} \mathrm{C}$ and grown until $80 \%$ confluence for a maximum of 20 passages.

\subsection{3-(4,5-Dimethylthiazol)-2,5-Diphenyltetrazolium Bromide (MTT) Reduction Test}

HEWL samples pre-incubated for $48 \mathrm{~h}$ under aggregating conditions in the absence or presence of $0.32 \mu \mathrm{M}$ compounds 1-6 were centrifuged and the pellets were dried under $\mathrm{N}_{2}$ to remove any compounds and DMSO, dissolved in cell culture medium at a final HEWL concentration of $2 \mu \mathrm{M}$ (monomer equivalents), and added to SH-SY5Y cells seeded in 96 -well plates for $24 \mathrm{~h}$ at $37^{\circ} \mathrm{C}$. The cell medium was then removed and the MTT solution $(0.5 \mathrm{mg} / \mathrm{mL}$ in RPMI) was added to the cells for $4 \mathrm{~h}$. The medium was then aspirated, and the formazan product was solubilized with cell lysis buffer $(20 \%$ SDS, $50 \% \mathrm{~N}$, N-dimethylformamide, $\mathrm{pH} 4.7$ ) for $1 \mathrm{~h}$, as previously described [62].

\subsection{Measurement of Caspase-3 Activity}

HEWL aggregates were formed in the absence or in the presence of $0.32 \mu \mathrm{M}$ of compounds $1-6$ as described in the previous section and then added to the cell culture medium of SH-SY5Y cells seeded on glass coverslips for $24 \mathrm{~h}$ at $2 \mu \mathrm{M}$ (monomer equivalents). Caspase-3 activity was then analyzed by using FAM FLICA $^{\mathrm{TM}}$ caspases 3 \& 7 solution (caspase $3 \& 7$ FLICA kit FAM-DEVDFMK, Immunochemistry Technologies, LLC, Bloomington, MN, USA). Cell fluorescence was analyzed by the TCS SP8 scanning confocal microscopy system (Leica Microsystems, Mannheim, Germany) equipped with an argon laser source, as previously reported [62]. A series of $1.0 \mu \mathrm{m}$ thick optical sections $(1024 \times 1024$ pixels) was 
taken through the cell depth for each sample using a Leica Plan Apo $63 \times$ oil immersion objective for fluorescence measurement at $488 \mathrm{~nm}$. The confocal microscope was set at optimal acquisition conditions, e.g., pinhole diameters, detector gain, and laser powers. Settings were maintained constant for each analysis.

\subsection{Statistical Analysis}

All data were expressed as means \pm standard error of mean (S.E.M). ANOVA followed by Bonferroni's post comparison test was used to compare different values.

\section{Conclusions}

In conclusion, we have provided experimental evidence of different effects of various substituents of the architecture of the 1,3,5-triarylbenzene molecule on the inhibition of the self-assembly of HEWL. We showed that $-\mathrm{OH},-\mathrm{OCH}_{3}$, and $-\mathrm{CH}_{3}$ groups as electron-donor groups positioned on aromatic rings have a low efficacy, whereas $-\mathrm{F}$ and $-\mathrm{NO}_{2}$ as electron-withdrawing groups have great efficacy in inhibiting amyloid formation by HEWL. Based on the results of this study and others, it is apparent that small aromatic compounds and functional groups appended on these aromatic molecules can have a profound effect on their ability to inhibit amyloid formation. These results may ultimately find applications in the development of potential amyloid inhibitors and, thus, possible use of these compounds as a therapeutic approach in the treatment of amyloid deposition diseases.

Supplementary Materials: Supplementary materials can be found at http://www.mdpi.com/1422-0067/20/22/ 5558/s1.

Author Contributions: Conceived and designed the experiments: H.R., F.C. Performed the experiments: H.R., R.T., A.B., and F.B. Analyzed the data: F.C., H.R., R.T., and C.C. Contributed reagents/materials/analysis tools: F.C., C.C., and H.R. Wrote the paper: H.R. and F.C. All authors revised the text and figures and agreed on their content.

Funding: This work was supported by a grant from the Research Council of the University of Payam Noor (49103/7).

Acknowledgments: We also thank the Iran National Science Foundation (INSF) and Hakim Sabzevari University for partial financial support of this work.

Conflicts of Interest: The authors declare no conflict of interest.

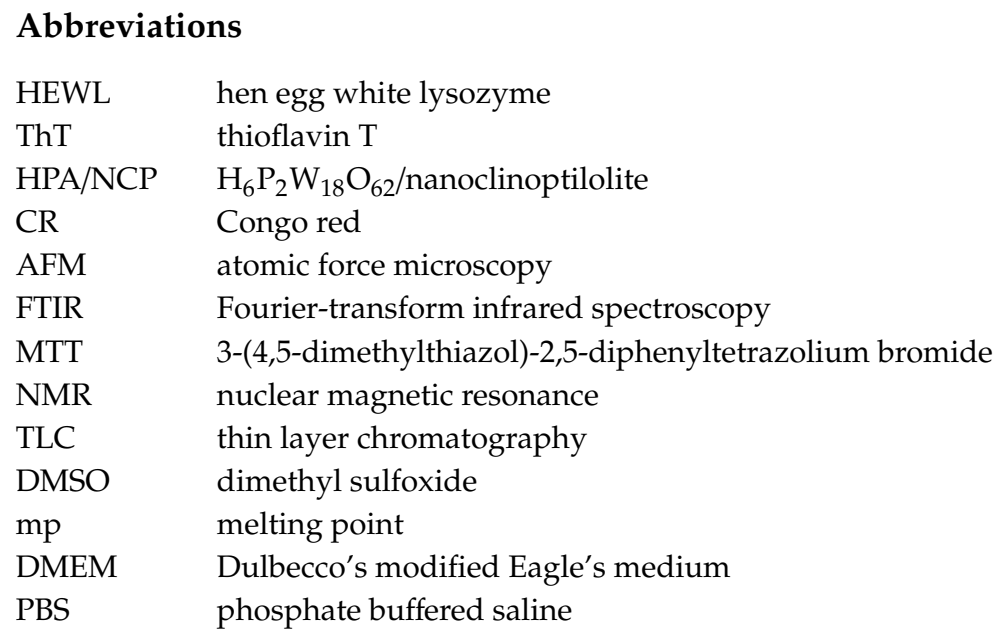

\section{References}

1. Chiti, F.; Dobson, C.M. Protein Misfolding, Amyloid Formation, and Human Disease: A Summary of Progress Over the Last Decade. Annu. Rev. Biochem. 2017, 86, 27-68. [CrossRef] [PubMed]

2. Sipe, J.D.; Benson, M.D.; Buxbaum, J.N.; Ikeda, S.-I.; Merlini, G.; Saraiva, M.J.M.; Westermark, P. Amyloid fibril proteins and amyloidosis: Chemical identification and clinical classification International Society of Amyloidosis 2016 Nomenclature Guidelines. Amyloid 2016, 23, 209-213. [CrossRef] [PubMed] 
3. Sgarbossa, A. Protein Aggregation: Emerging Strategies against Amyloidogenesis. Int. J. Mol. Sci. 2012, 13, 17121-17137. [CrossRef] [PubMed]

4. Dobson, C.M. Protein folding and misfolding. Nature 2003, 426, 884-890. [CrossRef] [PubMed]

5. Kayed, R.; McIntire, T.M.; Milton, S.C.; Glabe, C.G.; Head, E.; Thompson, J.L.; Cotman, C.W. Common Structure of Soluble Amyloid Oligomers Implies Common Mechanism of Pathogenesis. Science 2003, 300, 486-489. [CrossRef] [PubMed]

6. Baglioni, S.; Casamenti, F.; Bucciantini, M.; Luheshi, L.M.; Taddei, N.; Chiti, F.; Dobson, C.M.; Stefani, M. Prefibrillar Amyloid Aggregates Could Be Generic Toxins in Higher Organisms. J. Neurosci. 2006, 26, 8160-8167. [CrossRef]

7. Benilova, I.; Karran, E.; De Strooper, B. The toxic A $\beta$ oligomer and Alzheimer's disease: An emperor in need of clothes. Nat. Neurosci. 2012, 15, 349-357. [CrossRef]

8. Lee, C.-C.; Nayak, A.; Sethuraman, A.; Belfort, G.; McRae, G.J. A Three-Stage Kinetic Model of Amyloid Fibrillation. Biophys. J. 2007, 92, 3448-3458. [CrossRef]

9. Knowles, T.P.J.; Waudby, C.A.; Devlin, G.L.; Cohen, S.I.A.; Aguzzi, A.; Vendruscolo, M.; Terentjev, E.M.; Welland, M.E.; Dobson, C.M.; Waudby, C.; et al. An Analytical Solution to the Kinetics of Breakable Filament Assembly. Science 2009, 326, 1533-1537. [CrossRef]

10. Arosio, P.; Vendruscolo, M.; Dobson, C.M.; Knowles, T.P. Chemical kinetics for drug discovery to combat protein aggregation diseases. Trends Pharmacol. Sci. 2014, 35, 127-135. [CrossRef]

11. Fodero-Tavoletti, M.T.; Villemagne, V.L.; Rowe, C.C.; Masters, C.L.; Barnham, K.J.; Cappai, R. Amyloid- $\beta$ : The seeds of darkness. Int. J. Biochem. Cell Biol. 2011, 43, 1247-1251. [CrossRef] [PubMed]

12. Lannfelt, L.; Blennow, K.; Zetterberg, H.; Batsman, S.; Ames, D.; Harrison, J.; Maters, C.L.; Targum, S.; Bush, A.I.; Murdoch, R.; et al. Safety, efficacy, and biomarker findings of PBT2 in targeting A $\beta$ as a modifying therapy for Alzheimer's disease: A phase IIa, double-blind, randomized, placebo-controlled trial. Lancet Neurol. 2008, 7, 779-786. [CrossRef]

13. Soto, C.; Saborio, G.P.; Permanne, B. Inhibiting the conversion of soluble amyloid-beta peptide into abnormally folded amyloidogenic intermediates: Relevance for Alzheimer's disease therapy. Acta. Neurol. Scand. Suppl. 2000, 176, 90-95. [CrossRef] [PubMed]

14. Li, J.; Liu, R.; Lam, K.S.; Jin, L.W.; Duan, Y. Alzheimer's Disease Drug Candidates Stabilize A-b Protein Native Structure by Interacting with the Hydrophobic Core. Biophys. J. 2011, 100, 1076-1082. [CrossRef] [PubMed]

15. Ankarcrona, M.; Winblad, B.; Monteiro, C.; Fearns, C.; Powers, E.T.; Johansson, J.; Westermark, G.T.; Presto, J.; Ericzon, B.-G.; Kelly, J.W. Current and future treatment of amyloid diseases. J. Intern. Med. 2016, 280, 177-202. [CrossRef] [PubMed]

16. Blennow, K.; de Leon, M.J.; Zetterberg, H. Alzheimer's disease. Lancet 2006, 368, 387-403. [CrossRef]

17. Permanne, B.; Adessi, C.; Saborio, G.P.; Fraga, S.; Frossard, M.J.; van Dorpe, J.; Dewachter, I.; Banks, W.A.; van Leuven, F.; Soto, C. Reduction of amyloid load and cerebral damage in a transgenic mouse model of Alzheimer's disease by treatment with a beta-sheet breaker peptide. FASEB J. 2002, 16, 860-862. [CrossRef]

18. Chiti, F.; Stefani, M.; Taddei, N.; Ramponi, G.; Dobson, C.M. Rationalization of the effects of mutations on peptide and protein aggregation rates. Nature 2003, 424, 805-808. [CrossRef]

19. Belli, M.; Ramazzotti, M.; Chiti, F. Prediction of amyloid aggregation in vivo. EMBO Rep. 2011, 12, 657-663. [CrossRef]

20. Armstrong, A.H.; Chen, J.; McKoy, A.F.; Hecht, M.H. Mutations That Replace Aromatic Side Chains Promote Aggregation of the Alzheimer's A $\beta$ Peptide. Biochemistry 2011, 50, 4058-4067. [CrossRef]

21. Reinke, A.A.; Gestwicki, J.E. Structure?activity Relationships of Amyloid Beta-aggregation Inhibitors Based on Curcumin: Influence of Linker Length and Flexibility. Chem. Boil. Drug Des. 2007, 70, 206-215. [CrossRef] [PubMed]

22. Gazit, E. A possible role for pi-stacking in the self-assembly of amyloid fibrils. FASEB J. 2002, 16, 77-83. [CrossRef] [PubMed]

23. Tracz, S.M.; Abedini, A.; Driscoll, M.; Raleigh, D.P. Role of Aromatic Interactions in Amyloid Formation by Peptides Derived from Human Amylint. Biochemistry 2004, 43, 15901-15908. [CrossRef] [PubMed]

24. Milardi, D.; Sciacca, M.F.M.; Pappalardo, M.; Grasso, D.M.; la Rosa, C. The role of aromatic side-chains in amyloid growth and membrane interaction of the islet amyloid polypeptide fragment LANFLVH. Eur. Biophys. J. 2011, 40, 1-12. [CrossRef] [PubMed] 
25. Marek, P.; Abedini, A.; Song, B.; Kanungo, M.; Johnson, M.E.; Gupta, R.; Zaman, W.; Wong, S.S.; Raleigh, D.P. Aromatic Interactions Are Not Required for Amyloid Fibril Formation by Islet Amyloid Polypeptide but Do Influence the Rate of Fibril Formation and Fibril Morphology. Biochemistry 2007, 46, 3255-3261. [CrossRef]

26. Fauchère, J.L.; Charton, M.; Kier, L.B.; Verloop, A.; Pliska, V. Amino acid side chain parameters for correlation studies in biology and pharmacology. Int. J. Pept. Protein Res. 1988, 32, 269-278. [CrossRef] [PubMed]

27. Bemporad, F.; Taddei, N.; Stefani, M.; Chiti, F. Assessing the role of aromatic residues in the amyloid aggregation of human muscle acylphosphatase. Protein Sci. 2006, 15, 862-870. [CrossRef]

28. Marshall, K.E.; Morris, K.L.; Charlton, D.; O’Reilly, N.; Lewis, L.; Walden, H.; Serpell, L.C. Hydrophobic, Aromatic, and Electrostatic Interactions Play a Central Role in Amyloid Fibril Formation and Stability. Biochemistry 2011, 50, 2061-2071. [CrossRef]

29. Azriel, R.; Gazit, E. Analysis of the Minimal Amyloid-forming Fragment of the Islet Amyloid Polypeptide. J. Boil. Chem. 2001, 276, 34156-34161. [CrossRef]

30. Profit, A.A.; Felsen, V.; Chinwong, J.; Mojica, E.-R.E.; Desamero, R.Z.B. Evidence of $\pi$-stacking interactions in the self-assembly of hIAPP(22-29). Proteins Struct. Funct. Bioinform. 2013, 81, 690-703. [CrossRef]

31. Ahmad, E.; Ahmad, A.; Singh, S.; Arshad, M.; Khan, A.H.; Khan, R.H. A mechanistic approach for islet amyloid polypeptide aggregation to develop anti-amyloidogenic agents for type-2 diabetes. Biochemistry 2011, 93, 793-805. [CrossRef] [PubMed]

32. Ardah, M.T.; Paleologou, K.E.; Lv, G.; Khair, S.B.A.; Kazim, A.S.; Minhas, S.T.; Al-Tel, T.H.; Al-Hayani, A.A.; Haque, M.E.; Eliezer, D.; et al. Structure activity relationship of phenolic acid inhibitors of $\alpha$-synuclein fibril formation and toxicity. Front. Aging Neurosci. 2014, 6, 197. [CrossRef] [PubMed]

33. Ramshini, H.; Mannini, B.; Khodayari, K.; Ebrahim-Habibi, A.; Moghaddasi, A.S.; Tayebee, R.; Chiti, F. Bis(indolyl)phenylmethane derivatives are effective small molecules for inhibition of amyloid fibril formation by hen lysozyme. Eur. J. Med. Chem. 2016, 124, 361-371. [CrossRef] [PubMed]

34. Lakey-Beitia, J.; Berrocal, R.; Rao, K.S.; Durant, A.A. Polyphenols as therapeutic molecules in Alzheimer's disease through modulating Amyloid pathways. Mol. Neurobiol. 2015, 51, 466-479. [CrossRef] [PubMed]

35. Begum, A.N.; Jones, M.R.; Lim, G.P.; Morihara, T.; Kim, P.; Heath, D.D.; Rock, C.L.; Pruitt, M.A.; Yang, F.; Hudspeth, B.; et al. Curcumin structure-function, bioavailability, and efficacy in models of neuroinflammation and Alzheimer's disease. J. Pharmacol. Exp. Ther. 2008, 326, 196-208. [CrossRef]

36. Levy-Sakin, M.; Shreberk, M.; Daniel, Y.; Gazit, E. Targeting insulin amyloid assembly by small aromatic molrcules: Toward rational design aggregation inhibitors. Islets 2009, 1, 210-215. [CrossRef]

37. Krebs, M.R.; Wilkins, D.K.; Chung, E.W.; Pitkeathly, M.C.; Chamberlain, A.K.; Zurdo, J.; Robinson, C.V.; Dobson, C.M. Formation and seeding of amyloid fibrils from wild-type hen lysozyme and a peptide fragment from the beta-domain. J. Mol. Biol. 2000, 300, 541-549. [CrossRef]

38. Morozova-Roche, L.A.; Zurdo, J.; Spencer, A.; Noppe, W.; Receveur, V.; Archer, D.B.; Joniau, M.; Dobson, C.M. Amyloid Fibril Formation and Seeding by Wild-Type Human Lysozyme and Its Disease-Related Mutational Variants. J. Struct. Boil. 2000, 130, 339-351. [CrossRef]

39. Goda, S.; Takano, K.; Yamagata, Y.; Nagata, R.; Akutsu, H.; Maki, S.; Namba, K.; Yutani, K. Amyloid protofilament formation of hen egg lysozyme in highly concentrated ethanol solution. Protein Sci. 2000, 9, e369-e375. [CrossRef]

40. Cao, A.; Hu, D.; Lai, L. Formation of amyloid fibrils from fully reduced hen egg white lysozyme. Protein Sci. 2004, 13, 319-324. [CrossRef]

41. Swaminathan, R.; Ravi, V.K.; Kumar, S.; Kumar, M.V.; Chandra, N. Lysozyme: A model protein for amyloid research. Adv. Protein Chem. Struct. Biol. 2011, 84, 63-111. [PubMed]

42. Xu, M.; Shashilov, V.A.; Ermolenkov, V.V.; Fredriksen, L.; Zagorevski, D.; Lednev, I.K. The first step of hen egg white lysozyme fibrillation, irreversible partial unfolding, is a two-state transition. Protein Sci. 2007, 16, 815-832. [CrossRef] [PubMed]

43. Tayebee, R.; Jarrahi, M.; Maleki, B.; Mokhtari, Z.B.; Baghbanian, S.M.; Razi, M.K. A new method for the preparation of 1,3,5-triarylbenzenes catalyzed by nanoclinoptilolite/HDTMA. RSC Adv. 2015, 5, 10869-10877. [CrossRef]

44. Tayebee, R.; Jarrahi, M. ChemInform Abstract: H6P2W18O62/Nanoclinoptilolite as an Efficient Nanohybrid Catalyst in the Cyclotrimerization of Aryl Methyl Ketones under Solvent-Free Conditions. RSC Adv. 2015, 46, 21206-21214. [CrossRef] 
45. Mosmann, T. Rapid colorimetric assay for cellular growth and survival: Application to proliferation and cytotoxicity assays. J. Immunol. Methods 1983, 65, 55-63. [CrossRef]

46. Thornberry, N.A. The caspase family of cysteine proteases. Br. Med. Bull. 1997, 53, 478-490. [CrossRef]

47. Re, F.; Airoldi, C.; Zona, C.; Masserini, M.; la Ferla, B.; Quattrocchi, N.; Nicotra, F. Beta amyloid aggregation inhibitors: Small molecules as candidate drugs for therapy of Alzheimer's disease. Curr. Med. Chem. 2010, 17, 2990-3006. [CrossRef]

48. Wang, X.-Q.; Xia, C.-L.; Chen, S.-B.; Tan, J.-H.; Ou, T.-M.; Huang, S.-L.; Li, D.; Gu, L.-Q.; Huang, Z.-S. Design, synthesis, and biological evaluation of 2-arylethenylquinoline derivatives as multifunctional agents for the treatment of Alzheimer's disease. Eur. J. Med. Chem. 2015, 89, 349-361. [CrossRef]

49. Sang, Z.; Qiang, X.; Li, Y.; Yuan, W.; Liu, Q.; Shi, Y.; Ang, W.; Luo, Y.; Tan, Z.; Deng, Y. Design, synthesis and evaluation of scutellarein-O-alkylamines as multifunctional agents for the treatment of Alzheimer's disease. Eur. J. Med. Chem. 2015, 94, 348-366. [CrossRef]

50. Sacchettini, J.C.; Kelly, J.W. Therapeutic strategies for human amyloid diseases. Nat. Rev. Drug Discov. 2002, 1, 267-275. [CrossRef]

51. Tartaglia, G.G.; Cavalli, A.; Pellarin, R.; Caflisch, A. The role of aromaticity, exposed surface, and dipole moment in determining protein aggregation rates. Protein Sci. 2004, 13, 1939-1941. [CrossRef] [PubMed]

52. Makin, O.S.; Atkins, E.; Sikorski, P.; Johansson, J.; Serpell, L.C. Molecular basis for amyloid fibril formation and stability. Proc. Natl. Acad. Sci. USA 2005, 102, 315-320. [CrossRef] [PubMed]

53. Profit, A.A.; Vedad, J.; Saleh, M.; Desamero, R.Z. Aromaticity and amyloid formation: Effect of $\pi$-electron distribution and aryl substituent geometry on the self-assembly of peptides derived from hIAPP(22-29). Arch. Biochem. Biophys. 2015, 567, 46-58. [CrossRef] [PubMed]

54. Porat, Y.; Stepensky, A.; Ding, F.-X.; Naider, F.; Gazit, E. Completely different amyloidogenic potential of nearly identical peptide fragments. Biopolymers 2003, 69, 161-164. [CrossRef]

55. Hirata, K.; Sugimoto, T.; Konnob, T. Moriia, Amyloid-forming propensity of the hydrophobic non-natural amino acid on the fibril-forming core peptide of human tau. Bioorg. Med. Chem. Lett. 2007, 17, 2971-2974. [CrossRef]

56. Ramshini, H.; Mohammad-Zadeh, M.; Ebrahim-Habibi, A. Inhibition of amyloid fibril formation and cytotoxicity by a chemical analog of Curcumin as a stable inhibitor. Int. J. Boil. Macromol. 2015, 78, 396-404. [CrossRef] [PubMed]

57. Ladiwala, A.R.; Dordick, J.S.; Tessier, P.M. Aromatic small molecules remodel toxic soluble oligomers of amyloid beta through three independent pathways. J. Biol. Chem. 2011, 286, 3209-3218. [CrossRef] [PubMed]

58. Tayebee, R.; Savoji, K.; Razi, M.K.; Maleki, B. Environmentally friendly cyclotrimerization of substituted acetophenones catalyzed by a new nano-composite of $\gamma$-Al $2 \mathrm{O} 3$ nanoparticles decorated with H 5 PW $10 \mathrm{~V}$ 2 O 40. RSC Adv. 2016, 60, 55319-55326. [CrossRef]

59. Romanellia, G.P.; Ruiza, D.M.; Bideberripea, H.P.; Autinob, J.C.; Baronetti, G.T.; Thomasa, H.J. Silicagel-supported H6P2W18O62. 24H2O: A reusable catalyst to prepare diphenylmethyl (DPM) ethers. Arkivoc 2007, 2007, 1-8.

60. Sophianopoulos, A.J.; Rhodes, C.; Holcomb, D.N.; van Holde, K.E. Physical studies of lysozyme. I. Characterization. J. Biol. Chem. 1962, 237, 1107-1112.

61. Nilsson, M.R. Techniques to study amyloid fibril formation in vitro. Methods 2004, 34, 151-160. [CrossRef] [PubMed]

62. Cascella, R.; Capitini, C.; Fani, G.; Dobson, C.M.; Cecchi, C.; Chiti, F. Quantification of the Relative Contributions of Loss-of-function and Gain-of-function Mechanisms in TAR DNA-binding Protein 43 (TDP-43) Proteinopathies. J. Boil. Chem. 2016, 291, 19437-19448. [CrossRef] [PubMed]

(C) 2019 by the authors. Licensee MDPI, Basel, Switzerland. This article is an open access article distributed under the terms and conditions of the Creative Commons Attribution (CC BY) license (http://creativecommons.org/licenses/by/4.0/). 